\title{
A Model Proposal on Results of Physical and Mechanical Properties of Trakia Region Küfeki Stone Used at Early Period Ottoman Buildings
}

\author{
Gökhan UMAROĞULLARI ${ }^{1 *}$ (D), Semiha KARTAL ${ }^{2}$ (D) \\ ORCID 1: 0000-0002-7972-4049 \\ ORCID 2: 0000-0001-6274-488x \\ ${ }^{1}$ Kırklareli University, Faculty of Architecture, Department of Architecture, 39100, Kırklareli, Turkey. \\ ${ }^{2}$ Trakya University, Faculty of Architecture, Department of Architecture, 22100, Edirne, Turkey. \\ *email: ugokhan@klu.edu.tr
}

\begin{abstract}
Küfeki, is a building material because of its porous structure, which has low vapor permeability resistance and heat conductivity. The aim of this article is analyses for the features of küfeki stone with physical experiments used frequently in restoration applications nowadays. Here, it was compared with the küfeki stone samples used in historical buildings which approximately was built before 400 years and was taken from stone quarries in Trakia region. The water absorption test by volume under atmosphere pressure experiment was made based on TS 699 standards for analyzing of küfeki stone physical features. As a result of the experiments carried out, it is seen that the samples taken from the quarries absorb less water than the other samples taken from the historical buildings. This shows that the other stones are relatively deformed in time, under load and under various external influences.
\end{abstract}

Keywords: Küfeki, permeability, porosity, restoration, water absorption

\section{Erken Dönem Osmanlı Yapılarında Kullanılan Trakya Bölgesi Küfeki Taşının Fiziksel ve Mekanik Özelliklerinin Sonuçları Üzerine Bir Model Önerisi}

Öz

Küfeki, gözenekli yapısı nedeniyle buhar geçirgenlik direnci ve ısı iletkenliği düşük bir yapı malzemesidir. Bu makalenin amacı günümüzde restorasyon uygulamalarında sıkıkla kullanılan fiziksel deneyler ile küfeki taşının özelliklerini analiz etmektir. Burada Trakya bölgesindeki taş ocaklarından alınan örnekler ile yaklaşık 400 yıl önce inşa edilen tarihi yapılarda kullanılan küfeki taş örnekleri karşılaştırıldı. Küfeki taşının fiziksel özelliklerinin analizi için atmosfer basıncı altında su emme tayini deneyi TS 699 standartlarına göre yapılmısțtır. Yapılan deneyler sonucunda, ocaklardan alınan örneklerin tarihi yapılardan alınan diğer örneklere göre daha az su emdiği görülmüşsür. Bu, diğer taşların zamanla, yük altında ve çeşitli dış etkiler altında nispeten deforme olduğunu göstermektedir.

Anahtar Kelimeler: Küfeki, geçirgenlik, gözeneklilik, restorasyon, su emme

Citation/Atıf: Umaroğulları, G. and Kartal, S. (2021). A model proposal on results of physical and mechanical properties of Trakia Region küfeki stone used at early period Ottoman buildings. Journal of Architectural Sciences and Applications, 6 (2), 384-395.

DOI: https://doi.org/10.30785/mbud.918698 


\section{Introduction}

Which is known one of the oldest building materials, stone was a material integrated with the human during the historical eras. Stone, symbol of strength and trust, which was chosen at construction of permanent building since old ages, is a building material used by changing style and function. Because of its unique structure which stands without need any binder system in old ages, made it superior to the other materials. Küfeki stone which was kept its main material feature and was shaped to architecture in Roman, Byzantium and Ottoman periods; is carrying to use in nowadays because of its high aesthetic, climatic, easy applicable and strength features.

Many studies with küfeki stone were made (Demir and ilgi, 2014; Çapar, 2019). The materials used in historical building walls have an important place in terms of earthquakes, but there is no study on the importance of the material diversity in historical building walls in this respect. This article, written in this context, aims to reach some results at the end of the experiments of various materials taken from some Ottoman building walls in Istanbul. This work on limestone included various mechanical, chemical and metallurgical experiments and has an importance in the context of earthquakes.

The features of küfeki stone, at the moment taken from the quarry, change by time at the place used at buildings. The surface of the stone faced with the various physical and chemical effects during the building life and some deteriorations are happened in its internal structure also with its surface. While the reasons of the deterioration and deforming of the stone material used in historical buildings usually occur up to its internal structure, mechanical abrasions, water and moisture, atmospheric conditions and weather pollutions, users are also had the negative effects on the materials. So, it is possible the damaging and destroying of the buildings with the deteriorations up to various factor.

It was confirmed that the national resources are limited about physical and mechanical size of the küfeki stone which Mimar Sinan usually used in his works (Erguvanlı and Ahunbay, 1989; Arıoğlu, Odbay and Alper, 1994; Arıoğlu and Arığlu, 1997; Zarif, Tuğrul and Gürpınar, 1998). Some studies about experimental methods applied to the küfeki stones in literature are given below.

In one article, identifying the geological, physical, mineralogical, mechanical, technological, chemical features of limestone from Soğucak formation in Vize-Pınarhisar, (Kırklareli) area availability and suitability of limestones in restoration was researched. Building and quarry stones from Vize taken during the restoration of historical monuments were identified their inner structure features. Building stone experiments in TS 699, especially used in historical buildings of Istanbul and Trakia region from Pinarhisar and Vize areas, by taking their structural features, aim to use in restorations, were made (Dal, 2008). In one article, freeze-dried cycle of trimmed and unfinished tuff stones mentioned in a consolidation experiment study which samples were taken Manila from Mayamot mountain quarry, are investigated (Cristina Patemo and Elena Charolai, 2000).

Analyses were made with Optical Microscope, XRD, SEM-EDX machines in a such study which deterioration mechanism of the stones were investigated in Athena acropolis. 4 different stones were chosen for this experiment (white-hard stone, fossiliferous stone, a soft limestone and a hard sandstone). Porosity, ultrasonic acceleration, mechanical strength and water absorption values are investigated (Theoulakis and Bardanis, 2000). In another study, the porousness in 2 different sand stones (yellow and pink stones) taken from Strasburg cathedral which surface covered with black crust, are investigated. In study, lower mercury porousness, lower and weak capillary suction, slow drying, lower adhesion through the crust is seen.

It was taken advantages of RX, SEM analyses (Thomachot and Jeannette, 2000). Using accelerated aging tests, one study was made for long-term strength evaluation of yellow travertine stone (Dryingfreezing, dry-wet and salt crystallization). In the study, SEM and XRD for mineralogic structure, SEMEDS for crystal phases is used in the samples for dimension of $5 \times 5 \times 5 \mathrm{~cm}$ (Mutluhan and Aydın, 2011). In other study, uniaxial compressive strength, water absorption as flexing endurance and freeze-thaw effects on the strength effects of Ayazini tuff stone were investigated. XRF for main elements, XRD and SEM for mineralogical and petrographically features are used for Tuff stone usually used in Afyon 
province (Çelik, Akbulut, and Ergül, 2013). To find durability properties of Silivri limestone, polarizing microscope, XRD, SEM analyses are also used (Dal and Tokmak, 2020).

\subsection{Küfeki Stone, Physical Features and Usage Areas}

Küfeki is an organic residual stone consists of sediments as silica and fossil (as oyster and mussel), light beige, light yellow, gray colors, thin granular and sandy looking, fossiliferous, porous and crystalline compact stone. It is a kind of stone which easy trimmed before taking from quarry because of softly, later hardened by taking $\mathrm{CO}_{2}$ gas from air. Its durability further increases by comparing with concrete in time and its life approximately reaches to 2500 years. While mechanical sizes (pressure, tensile, sliding strengths) increases by reacting with $\mathrm{CO}_{2}$ in the air, as a result of carbonation, empty spaces of its structure decreases and its resistance increases against to outer effects (water, gas emissions etc.) (Erguvanlı and Ahunbay, 1989). It has water in its structure and while some parts vaporize, some other parts are trapped in a layer because of carbonation from outer boundary to inner parts. The water in structure is affected to the loading pressure of the building under dynamic load strength (Tuncel and Arıoğlu, 1998).

By reacting with $\mathrm{CO}_{2}$ in the air because of speedy carbonation under atmospheric conditions, some its empty spaces fill with $\mathrm{Ca}\left(\mathrm{HCO}_{3}\right)_{2}$ of küfeki stone, while its porosity and water absorption increases its resistance and density decrease. As a result of the explained carbonation, the improvement rise of compressive strength is similar with concrete. Strengths after 30 days of quarry, is seen as $\mathrm{fb} \approx 45$ $\mathrm{MPa}$, at the experiments made on full of shells küfeki stone. Information about mechanical magnitude (compressive strength, Schmidt hammer assays, ultrasound speed assays, statistical relations between compressive strength and the tensile strength) observed from experiments, are dealt in some resources (Gentürk, Gündüz, and Sarışık, 1995; Arıoğlu and Arıoğlu, 1997). The ratio of compressive strength and the tensile strength is determined as 11-12 (Arıoğlu and Arıoğlu, 1997).

This value is referred as a structure of high-power absorption capacity in another word ductile material. Elasticy modulus/compressive strength is found as $\approx 720$ (Erguvanlı and Ahunbay, 1989). It shows a harmony with value belonged to concrete material. Existence shells in küfeki stone are orientation randomly in another word three-dimensional style and height/diameter ratios usually are big.

It shows this characteristic also shows a typic "fibrous composite material" feature. So, under triaxial stress (earthquake installation), it can be told to show for küfeki stone with plenty of shell as effective ductile behavior. In terms of the durability of küfeki stone in time, the shells have an important effect to prevention the disturbance of matrix.

A type of küfeki stone which has as an independent porous structure and has a few empty spaces smaller than $0.1 \mu \mathrm{m}$, is affected less from outer effects (temperature changes, wetting-drying, freezethaw, industrial emissions, sea salts etc.).

In general, it is known that natural stones are porous materials. If empty space in unit volume is high so the porosity is also high. When duty cycle is increased, it is seen that heat absorbance is also increased but compressive strength is decreased. Porosity and pore size of the stone distribution is an important factor against off for destroying behaviors (Addleson, 1972). In case of continuance of the material space, water and moisture permeability value increases. Big, perforated stones easily absorb big amount of water. In terms of the high value, the strength and the economic value of the stone decrease. The porosity of natural stones which are accepted as a good quality, changes between $0.0002 \%-0.5 \%$. When pores are increased then the durability of the stone is decreased. For that reason, usually thin-crystallized stones are chosen. The porousness value up to TS 699 should be lower than $2 \%$. Physical features of the küfeki stone are given in detail at Table 1. 
Table 1. Physical features of küfeki stone (Erguvanlı and Ahunbay, 1989)

\begin{tabular}{ll}
\hline Porous, first from quarry with density & $\mathrm{\gamma} \approx 2.2 \mathrm{t} \mathrm{m}^{-3}$ \\
Specific Weight & $\rho \approx 2,5$ \\
Porosity & $\mathrm{p} \approx 12-13 \%$ \\
Water absorption & $\mathrm{w} \approx 5 \%$ \\
(Weight) and pressure resistance & $\mathrm{f} \approx \mathrm{fO}=20-30 \mathrm{MPa}$ \\
Strength after 30 days & $\mathrm{fb} \approx 45 \mathrm{MPa}$ \\
Compression strength/tensile strength ratio & $11-12$ \\
Elasticity modulus/compression strength & $\approx 720$
\end{tabular}

Küfeki stone up to its features of structural content, is widely used at all in and out places of the buildings. In terms of easy Not only the facade coating but it is found rich and different usage area because of easy carving. Küfeki stone, frequently is used at works which required as aesthetics, art and kindship at inner area, floor tiling, arches, columns, door frames, bay windows, capstones, fireplaces, garden arrangements, reliefs, portals, mihrabs, minbars, bird houses, gargoyles, alms stones.

Because of the quarries are close, lighter to the other stones, easy transportation, economy, time saving, soft state when taken from quarry, easy carving, etc. Küfeki stone was one of the main materials of architecture at Roman, Byzantium, Ottoman period. Besides that, creating easy modular element, variety usage, long life (2000-2500 years), chemical uniformity with mortars (Khorasan and other mortars), providing adherence at site was put this stone to forward.

\section{Material and Method}

This study was made with 5 chosen buildings belonged to Early Ottoman Period in Edirne province. Chosen buildings are especially the restoration phase' buildings which modern techniques were applied with küfeki stone taken from regional quarry. Stone samples taken from these buildings were compared to evaluated with regional quarry stone samples with the aim of variations in time by using some analysis techniques.

The experiments applied to building stones, are identified with in the scope of standards for TS 699 (TS 699, 2009). In this context physical experiments are made for identification of küfeki stone features based on this standard. Water absorption in volume and porosity experiments under atmosphere were completed for küfeki stone. Samples were waited at full pool until saturated state for porosity experiment, weighed and calculated how much water absorbed in their contexture for water absorption experiment. The obtain data from these experiments were evaluated with calculation method of standards. Considering to space shaped as sphere and cylinder in the samples which represent the küfeki stone, unit cell model was created and up to this a mathematical model was created for identifying of strength-space relation.

As a result of helping of obtained data from applied experimental methods, when new stones from active quarries are used and changed with küfeki stone which was used at Early Ottoman Period at restoration applications, expecting performance was evaluated. As well as comparing the samples taken from same buildings at same period between each other, the samples taken from 2 different quarries were compared between each other (Umaroğulları, 2015).

Samples taken for experiments were obtained from 5 different buildings which their restoration process goes on (Early-Stage Ottoman Buildings) and 2 different stone quarries (in Trakia region). Experiments are made with 5 samples taken which their dimensions are $5 \times 5 \times 5 \mathrm{~cm}$. And the quarry samples had also the same dimensions for equal comparing.

Test samples taken from buildings are coded as $(B),(C),(F),(H),(I)$, and from stone quarries as (D), (G).

Density should be $2.40-2.70 \mathrm{gr} \mathrm{cm}-3$ and water absorption percent by weight should be \% 0.2-0.6 to TS 699. Admitted density of küfeki stone with shell and mussel should be $2.2 \mathrm{gr} \mathrm{m}-3$ and water absorption percent by weight should be $5 \%$. 
Table 2. Values of density $\left(\mathrm{gr} \mathrm{cm}^{-3}\right)$ and water absorption by weight (as) under atmospheric pressure of samples belonged to buildings and stone quarry

\begin{tabular}{|c|c|c|c|c|}
\hline $\begin{array}{l}\text { Building taken } \\
\text { from sample }\end{array}$ & Samples & $\begin{array}{c}\text { Sample } \\
\text { Code }\end{array}$ & $\begin{array}{c}\text { Water absorption } \\
\text { ratio \% by weight (As) }\end{array}$ & Density $\left(\mathrm{gr} \mathrm{cm}^{-3}\right)$ \\
\hline \multirow{5}{*}{$\begin{array}{c}\text { Süleymanpaşa } \\
\text { Mosque (B) }\end{array}$} & & B9 & 6.04 & 2.12 \\
\hline & & B10 & 9.57 & 1.84 \\
\hline & & B11 & 8.40 & 2.0 \\
\hline & & B12 & 9.39 & 1.96 \\
\hline & & B13 & 7.20 & 2.0 \\
\hline \multirow{4}{*}{$\begin{array}{c}\text { Çakırağa } \\
\text { Mosque (C) }\end{array}$} & & C9 & 6.67 & 1.92 \\
\hline & & C10 & 8.09 & 1.88 \\
\hline & & C11 & 10.45 & 1.76 \\
\hline & & C12 & 6.12 & 1.96 \\
\hline \multirow{5}{*}{$\begin{array}{l}\text { Saatli Medresa } \\
\text { (F) }\end{array}$} & & F9 & 8.24 & 2.04 \\
\hline & & $\mathrm{F} 10$ & 7.31 & 2.08 \\
\hline & & F11 & 7.20 & 2.00 \\
\hline & & F12 & 5.10 & 2.04 \\
\hline & & $\mathrm{F} 13$ & 6.27 & 2.04 \\
\hline \multirow{5}{*}{$\begin{array}{l}\text { Beylerbeyi } \\
\text { Tomb }(\mathrm{H})\end{array}$} & & $\mathrm{H9}$ & 6.04 & 2.12 \\
\hline & & $\mathrm{H} 10$ & 4.29 & 2.24 \\
\hline & & $\mathrm{H} 11$ & 6.54 & 2.08 \\
\hline & & $\mathrm{H} 12$ & 4.81 & 2.16 \\
\hline & & $\mathrm{H} 13$ & 5.56 & 2.16 \\
\hline \multirow{5}{*}{$\begin{array}{l}\text { Kasımpaşa } \\
\text { Mosque (I) }\end{array}$} & & 19 & 10.00 & 1.84 \\
\hline & & 110 & 9.79 & 1.88 \\
\hline & & $\mid 11$ & 7.84 & 2.04 \\
\hline & & 112 & 9.13 & 1.84 \\
\hline & & 113 & 12.09 & 1.72 \\
\hline \multirow{5}{*}{$\begin{array}{l}\text { Süloğlu Stone } \\
\text { Quarry (D) }\end{array}$} & & D9 & 3.40 & 2.12 \\
\hline & & D10 & 2.33 & 2.40 \\
\hline & & D11 & 4.31 & 2.04 \\
\hline & & D12 & 2.62 & 2.44 \\
\hline & & D13 & 3.73 & 2.36 \\
\hline \multirow{5}{*}{$\begin{array}{l}\text { Pınarhisar } \\
\text { Stone Quarry } \\
\text { (G) }\end{array}$} & & G9 & 9.81 & 2.12 \\
\hline & & G10 & 6.55 & 2.20 \\
\hline & & G11 & 6.71 & 2.26 \\
\hline & & G12 & 5.36 & 2.24 \\
\hline & & G13 & 5.26 & 2.28 \\
\hline
\end{tabular}

When samples taken from buildings, are examined, it is seen that B, C, F and I samples are suitable for percent by weight and not suitable for density. It can be said that sample taken from $\mathrm{H}$ building is suitable for percent by weight and average for density.

Samples taken from stone quarries up to table 2; It can be said that sample taken from D quarry is average for percent by weight and suitable for density. Porosity degree of $D$ samples are low as $3.81 \%$ but suitable. It can be said that sample taken from $\mathrm{G}$ quarry is suitable for percent by weight and average for density.

Density of heavy sample is much up to this. It is seen that there is a correlation between weight and density. It is also seen that the averages of weight and density of samples taken from $D$ and $G$ quarries are the highest ones and there against, density of samples taken from $C$ and I are the lowest ones (Figure 1). Lowest stones are both much water absorbed and are broken under low loads. And this shows that the samples are weaker. 


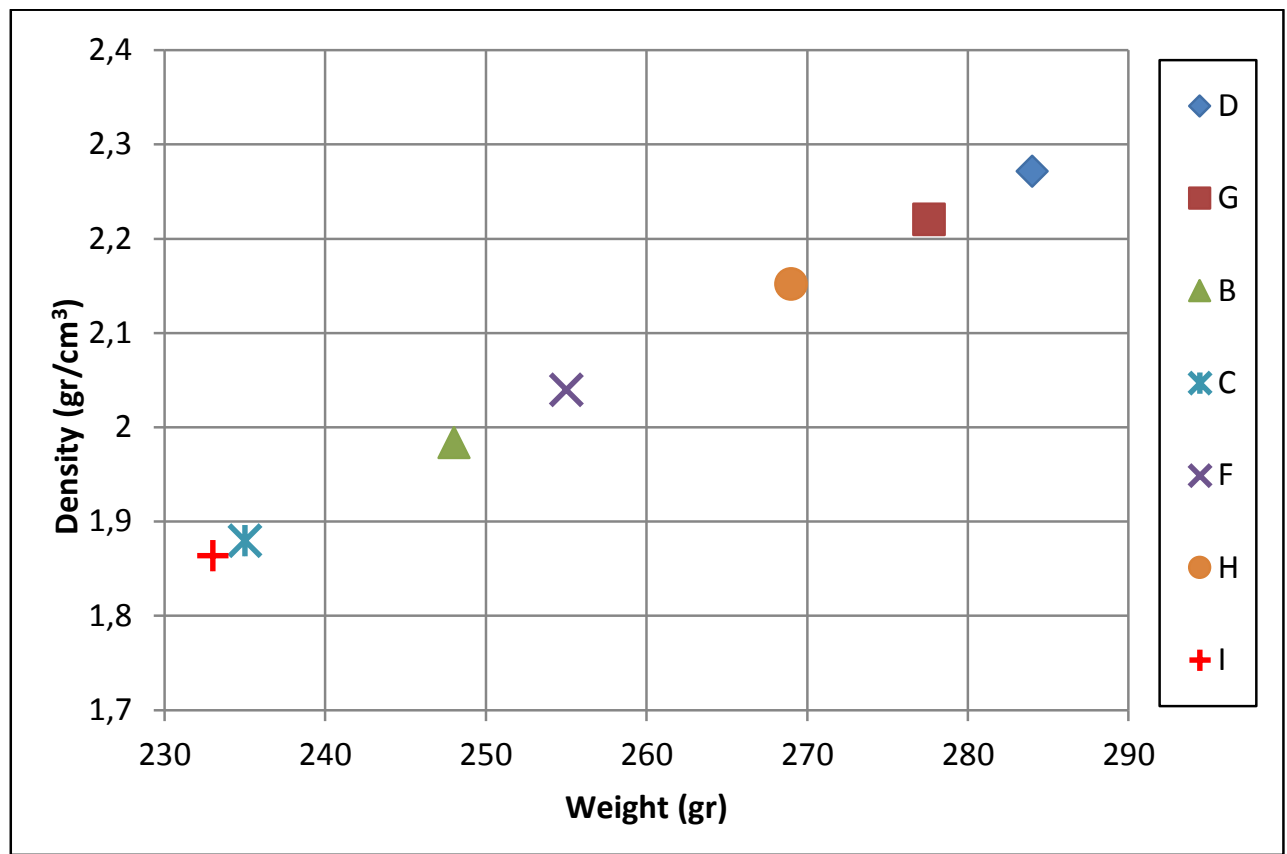

Figure 1. Average unit weight and density variation graphic

By looking to average density values, it was seen that samples taken from $D$ and $G$ quarries are the highest ones, but samples taken from $\mathrm{C}$ and I are the lowest ones (Figure 2). It is expected result that unused stones are given the higher values.

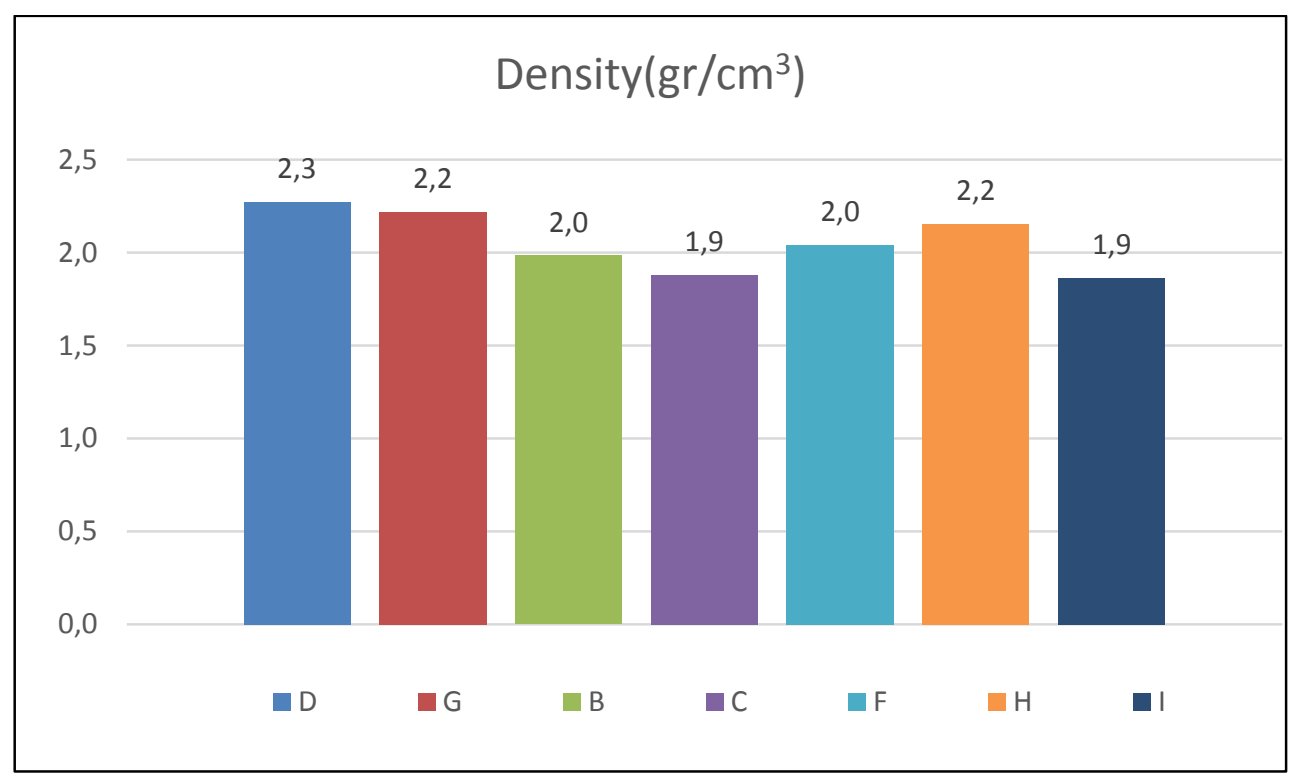

Figure 2. Comparing of average unit weight and density values

Stone porosity should be lower than $2 \%$ to TS 699. Admitted porosity of küfeki stone with shell and mussel should be $12-13 \%$ and water absorption percent by weight.

Samples taken from building B to the contrary being under loads and affected from the environmental conditions, are suitable stones with porosity for value of $9.12 \%$. Samples taken from building $\mathrm{C}$ are suitable stone with porosity for value of $8.40 \%$. Samples taken from building $\mathrm{F}$ are suitable stone with porosity for value of $7.69 \%$. Samples taken from building $\mathrm{H}$ are suitable stone with porosity for value of $6.04 \%$. Samples taken from building I are suitable stone with porosity for value of $8.40 \%$ to the contrary close to the borders. Samples taken from building $D$ are low but suitable stone with porosity for value of $3.81 \%$. Samples taken from building $G$ are suitable stone with porosity for value of $7.69 \%$. 
Journal of Architectural Sciences and Applications, 2021, 6 (2), 384-395.

Table 3. Porosity experiment results of samples belonged to buildings and stone quarries

\begin{tabular}{|c|c|c|c|c|c|c|}
\hline $\begin{array}{l}\text { Sample } \\
\text { Building }\end{array}$ & Code & Initial Weight(gr) & After 24 hours & After 72 hours & $\begin{array}{l}\text { After } 144 \text { hours } \\
\text { in water }\end{array}$ & $\begin{array}{c}\text { Average } \\
\text { Water } \\
\text { Absorption } \\
\% \\
\end{array}$ \\
\hline \multirow{5}{*}{ B } & B9 & 265 & 278 & 279 & 281 & \multirow{5}{*}{9.12} \\
\hline & B10 & 230 & 247 & 250 & 252 & \\
\hline & B11 & 250 & 267 & 269 & 271 & \\
\hline & B12 & 245 & 264 & 266 & 268 & \\
\hline & B13 & 250 & 264 & 266 & 268 & \\
\hline \multirow{4}{*}{$\mathrm{C}$} & C19 & 240 & 252 & 254 & 256 & \multirow{4}{*}{8.40} \\
\hline & C10 & 235 & 250 & 252 & 254 & \\
\hline & C11 & 220 & 240 & 241 & 243 & \\
\hline & C12 & 245 & 257 & 258 & 260 & \\
\hline \multirow{5}{*}{$\mathrm{F}$} & F9 & 255 & 272 & 274 & 276 & \multirow{5}{*}{7.69} \\
\hline & F10 & 260 & 276 & 277 & 279 & \\
\hline & F11 & 250 & 265 & 266 & 268 & \\
\hline & F12 & 255 & 265 & 266 & 268 & \\
\hline & F13 & 255 & 268 & 269 & 271 & \\
\hline \multirow{5}{*}{$\mathrm{H}$} & H9 & 265 & 277 & 279 & 281 & \multirow{5}{*}{6.04} \\
\hline & $\mathrm{H} 10$ & 280 & 288 & 289 & 292 & \\
\hline & $\mathrm{H} 11$ & 260 & 273 & 274 & 277 & \\
\hline & $\mathrm{H} 12$ & 270 & 279 & 280 & 283 & \\
\hline & $\mathrm{H} 13$ & 270 & 281 & 282 & 285 & \\
\hline \multirow{5}{*}{ I } & 19 & 230 & 249 & 251 & 253 & \multirow{5}{*}{10.63} \\
\hline & $\mid 10$ & 235 & 254 & 256 & 258 & \\
\hline & $\mid 11$ & 255 & 273 & 273 & 275 & \\
\hline & $\mid 12$ & 230 & 247 & 249 & 251 & \\
\hline & 113 & 215 & 236 & 239 & 241 & \\
\hline \multirow{5}{*}{ D } & D9 & 265 & 273 & 274 & 274 & \multirow{5}{*}{3.81} \\
\hline & D10 & 300 & 307 & 307 & 307 & \\
\hline & D11 & 255 & 265 & 266 & 266 & \\
\hline & D12 & 305 & 312 & 313 & 313 & \\
\hline & D13 & 295 & 305 & 306 & 306 & \\
\hline \multirow{5}{*}{ G } & G9 & 265 & 288 & 290 & 291 & \multirow{5}{*}{7.69} \\
\hline & G10 & 275 & 292 & 292 & 293 & \\
\hline & G11 & 283 & 300 & 301 & 302 & \\
\hline & G12 & 280 & 293 & 294 & 295 & \\
\hline & G13 & 285 & 298 & 299 & 300 & \\
\hline
\end{tabular}

Average water absorption values for all taken samples are compared (Figure 3). 


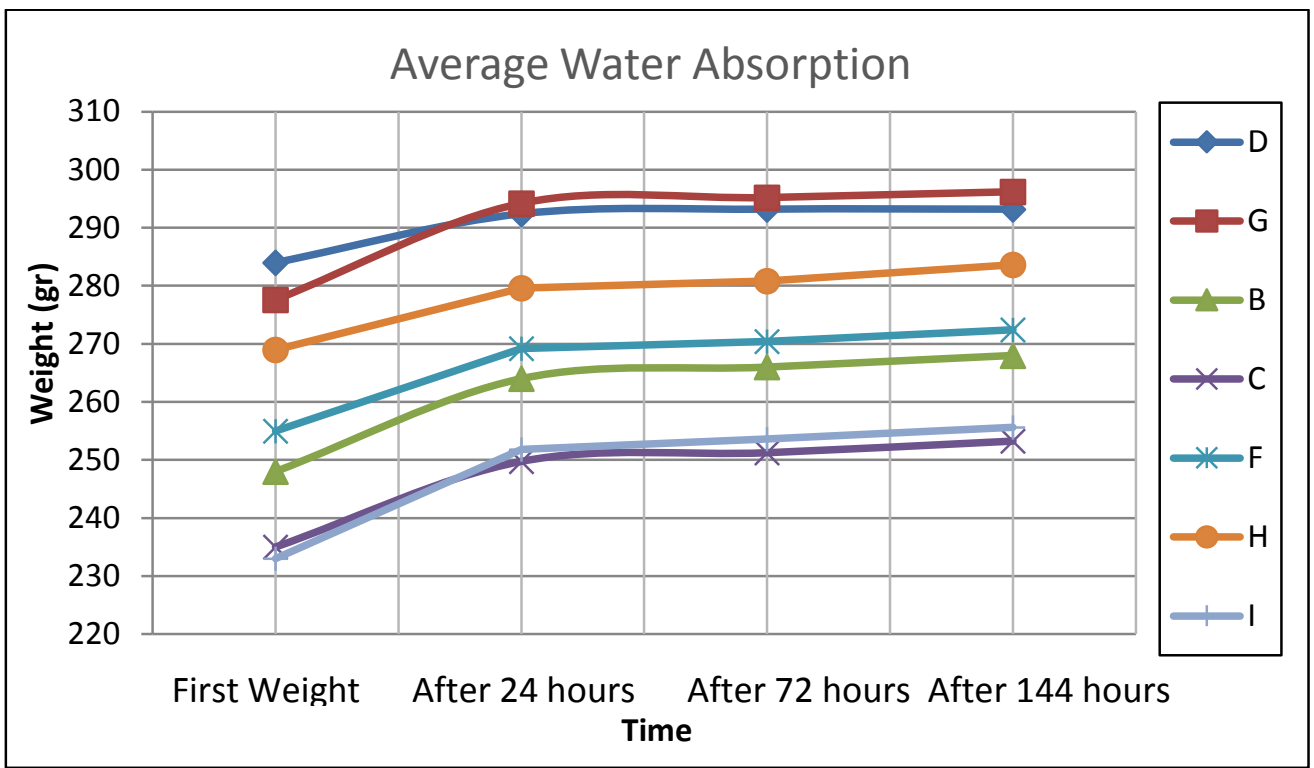

Figure 3. Comparing of average water absorption values

When the average water absorption values were compared it was seen that the lowest water absorption value was sample taken from $\mathrm{D}$ quarry as $3.14 \%$. $\mathrm{H}$ sample as $5.15 \%$ and $\mathrm{G}$ sample as $5.15 \%$ are followed. Most water absorption is seen for I samples as $8.84 \%$. Samples taken from quarries are absorbed less water than the other samples. This shows that the other stones were affected from environmental conditions and under load so were deformed. Deformed stones were become as porous and reached higher water absorption level. And this is affected at the freeze-thaw cycle as deformed.

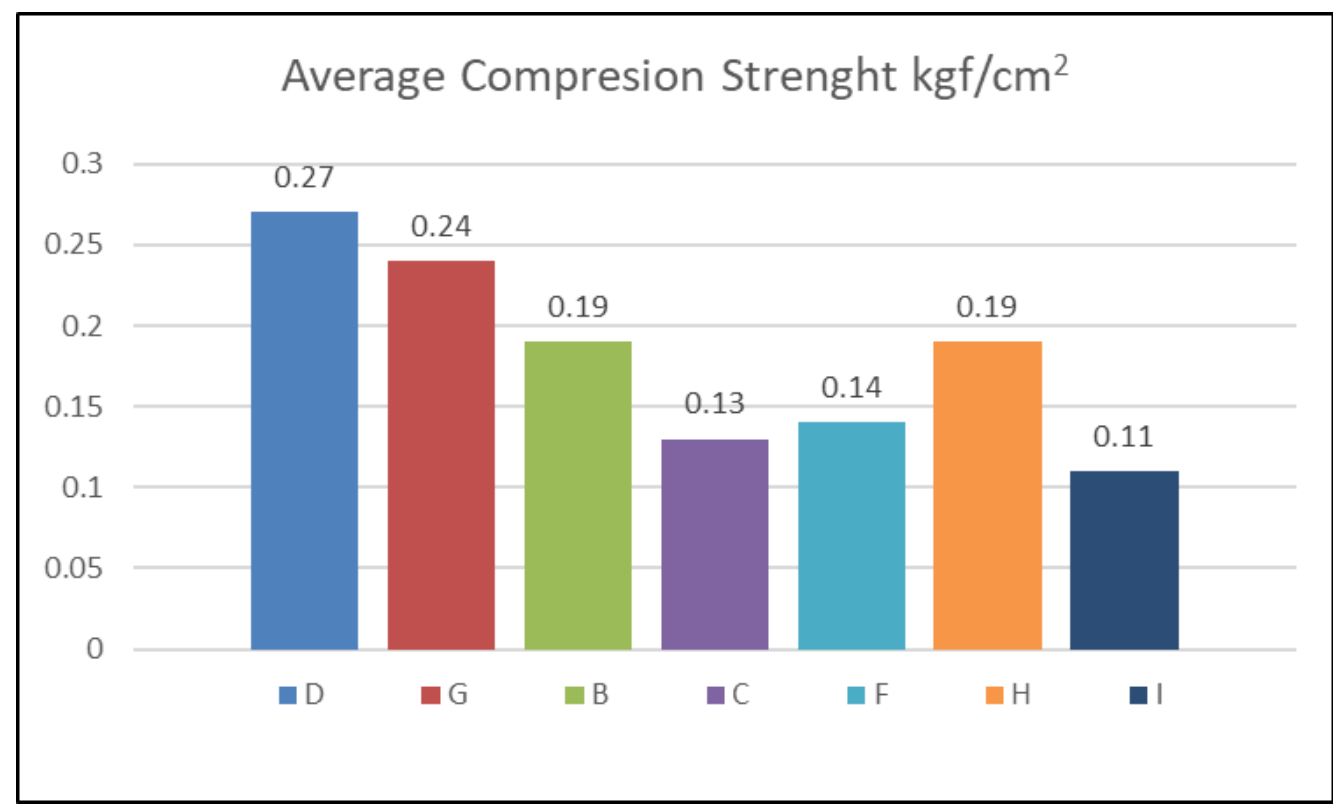

Figure 4. Comparison of the average compressive strengths of the samples

Looking at the average compressive strengths, it is seen that the most durable stones are the new stones taken from the quarry, as expected. It is seen that the Süleymanpaşa and Beylerbeyi Mosques have the highest compressive strength among the building samples, while the Kasımpaşa Mosque sample has the lowest (Figure 4). Experimental and theoric values are compared at Table 4.

\section{Findings and Evaluations}

In the literature, Eudier and Griffiths have developed mathematical models that define the relation of the bearing gap to spherical geometry. However, as is known, the gaps in the material have different geometric shapes. When strength formulas are developed, it is necessary to consider the different geometric structures of the cavities (Eudier, 2014; Griffits, Davies and Basset, 2013). 
In this study, gaps as spherical and cylindrical spaces are formed unit cell model (Figure 5).

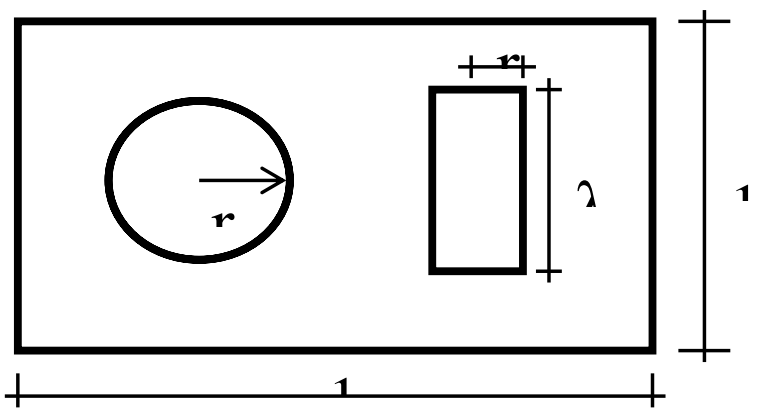

Figure 5. Unite Cell Model

Strength;

$\sigma=\sigma_{0}\left[1-\pi\left(r^{2}+r^{2}{ }_{2}\right)\right]$

can be calculated with this formula. Here $\sigma 0$ strength without space, $r 1$ radius of sphere, $r 2$ radius of cylinder, 1 is represents as constant number. Total porosity up to unit cell model $p$ means;

$\mathrm{P}=\frac{4}{3} \pi r_{1}^{3}+\lambda \pi r_{2}^{3}$

$\frac{\frac{4}{3} r_{1}^{3}}{\frac{4}{3} r_{1}^{3}+\lambda r_{2}^{3}}=\beta$

shows the ratio of the gaps.

$\beta=\frac{\frac{4}{3}}{\frac{4}{3}+\frac{\lambda r_{2}^{3}}{r_{1}^{3}}}$

can be written as.

From here and equation which define the total porosity;

$\mathrm{r}_{1}=\left(\frac{3}{4} \frac{\beta}{\pi} P\right)^{1 / 3} \quad \mathrm{r}_{2}=\left[\frac{P}{2 \pi} \beta\left(\frac{1}{\beta}-1\right)\right]^{1 / 3}$

$r_{1}$ and $r_{2}$ radii are calculated. If these values are put at the equation which define the strenght;

$\sigma=\sigma_{0}\left[1-\pi^{1 / 3} \beta^{2 / 3} P^{2 / 3}\left[\left(\frac{3}{4}\right)+\lambda^{-2 / 3}\left(\frac{1}{\beta}-1\right)^{2 / 3}\right]\right]$

(proposed equation) is obtained this equation.

Table 4. Strength and porosity values of samples at the experimental and theoretical experiments

\begin{tabular}{|c|c|c|}
\hline \multicolumn{2}{|l|}{ Experimental Values } & \multirow{2}{*}{$\begin{array}{l}\text { Theoric Values } \\
\text { (calculated with proposed equation } \\
\left.\mathrm{kgf} / \mathrm{cm}^{2}\right)\end{array}$} \\
\hline Strength $\left(\mathrm{kgf} \mathrm{cm}^{-2}\right)$ & Porosity (\%) & \\
\hline 0.27 & 0.11 & 0.26585 \\
\hline 0.24 & 0.13 & 0.2438 \\
\hline 0.19 & 0.19 & 0.1835 \\
\hline 0.13 & 0.24 & 0.138 \\
\hline 0.11 & 0.27 & 0.1123 \\
\hline
\end{tabular}

In the calculations made, $\beta$ value was found to be 0.6 and $\lambda$ value was found to be 0.2 . These values show that the ratio of cavities with spherical geometry is 0.6 and the ratio of cylindrical cavities in change form is 0.4 (Eudier, 2014; Griffits, Davier, and Basset, 2013). 


\section{Result and Suggestions}

Pores in the building stones, even at the micro levels. Some of these pores are open to the outside, others are closed. Open and capillary cavities are important for water absorption and permeability. These pores significantly affect the unit weight of the building stone, water absorption, permeability, durability, strength, heat and sound insulation. The unit volume weight should not be less than $2.55 \mathrm{~g}$ $\mathrm{cm}-3$ so that the stones can be used in construction. The specific weight of natural stones is $2.7 \mathrm{~g} \mathrm{~cm}-$ 3 on average and even less in porous stones (Akman, 1987).

The specific gravity is the ratio of the density to the weight of pure water at $4{ }^{\circ} \mathrm{C}$. As the amount of specific gravity contained in the stone increases, the economic value also increases. The specific gravity of all sedimentary rock types is greater than $2.55 \mathrm{~g} \mathrm{~cm}-3$ according to standards. The water absorption rate by weight is a value that expresses how much water can be absorbed without any pressure of the rock. The ability of water absorbing depends on whether the stone is compact or not (Ediz, 2002). Generally, if the water absorption is too much, the porosity is excessive, the voids and cracks are very high, the amount of decomposition is high. On the other hand, the low water absorption shows that the mechanical properties are high such as pressure resistance and modulus of elasticity.

The lower limit values for the water absorption rate specified in the standards shall be in accordance with the results of the formulas applied in the tests and the test results. Furthermore, according to TS 1469 (natural stones used as coatings), natural stones should not have a water absorption value grater then $1.8 \%$ by weight in atmospheric pressure. This value should be smaller than $0.75 \%$ for granite and diabase, $2 \%$ for serpentine and $0.4 \%$ for marble (TS 1469, 2006).

Porosity is the space that the stone in the unit volume contains. Natural stones are hollow materials, and the large size of porosity means that the stone contains a large many voids. As the void filling ratio increases, the pressure resistance of the material decreases and the heat absorption value increases. The porosity and pore size distribution of the stone is an important factor determining the behavior against the damage (Addleson, 1972). If the material void is continuous, the water and vapor permeability value also increase. Stones that are big in porosity absorb water easily with much water. Therefore, it becomes unstable against frost. The value of water absorption in natural building stones should be $>1.8 \%$ (TS 1467, 2005). The porosity of natural stones, considered as good quality, varies between $0.002 \%$ and $0.5 \%$. Increasing the voids reduces the durability of the stone. For this reason, as fine as possible, crystalline stones are preferred.

As a result of the pressure and porosity experiments, it was seen that the samples $D$ and $G$ were suitable for the restored structures. D samples are more robust, less porous and have lower water absorption capacities than $G$ samples. However, it is necessary to wait for a period to throw the quarry moisture. Old samples taken from five different structures showed that stones were under certain loads over time, influenced by environmental factors and as a result, deformed. These stones became more fragile, partly losing their strength. The lowest compressive strength is seen in the I sample. It can be said about the fact that the structure belong to the samples are in a place which is under water in the winter months because of the overflow of the Meriç River and that the pressure resistance of the samples is also adversely affected.

When the average water absorption values are considered, it is understood that this process stops after the saturation point where the water absorption processes of the samples continue to a certain point. At this point the suction process is stabilized. As a result of the calculations made, it is seen that the water absorption rates of the new samples taken from the quarries are lower than the other samples. The stones are heavier than the other samples and the porous structures are lower. They are not deformed. For this reason, the average water absorption values are lower than the samples taken from the structures. Only the $\mathrm{H}$ samples contain an inverse result. This brings the idea to mind that the samples were taken from a stone that had been altered in the structure during a restored period. 
In this study, it was observed that the pores in the cubic stones tested had spherical and flat cylindrical geometry. Unit cell model was created based on this observation. At the strength-porosity model, which was developed based the fact on that the stresses were changed around the pore, the values are obtained very close to the experimental results. However, the coefficients that define the model may vary depending on the pore geometry of the cubic stone and the distribution of the pores. For this reason, it is necessary to examine the stones for which the strengths are to be estimated under a microscope. The model recommended for cubic stones with the same pore geometry and distribution.

\section{Acknowledgment and Information Note}

This article has been produced from the doctoral dissertation completed in the Department of Architecture, Trakya University Institute of Science. The article complies with national and international research and publication ethics. Ethics committee permission was not required for the study.

\section{Author Contribution and Conflict of Interest Declaration Information}

All authors contributed equally to the article. There is no conflict of interest.

\section{References}

Addleson, L. (1972). Materials for building. Lliffe Press, Book I (Architect and building news books), Canada.

Ahunbay, Z. (1988). Mimar Sinan yapılarında kullanılan yapım teknikleri ve malzeme. Mimarbaşı Kocasinan yaşadığı çağ ve eserleri. 1. (s.531-538). İstanbul.

Akman, S. (1987). Yapı malzemeleri. iTÜ Inşaat Fakültesi Mühendislik Dergisi, 161s, İstanbul.

Arıoğlu, E., Odbay, O. and Alper, H. (1994). İstanbul-Sazlıbosna, küfeki taşının mühendislik büyüklüklerinin araştırılması, 15. Yıl Sempozyumu, Çukurova Üniversitesi, Müh. Mim. Fak, Adana, Turkey, s.311-326.

Arıoğlu, N. and Arıoğlu, E. (1997). Mimar Sinan'ın seçtiği taş: Küfeki ve çekme dayanımı, 14. Türkiye İnşaat Mühendisliği Teknik Kongresi, İzmir, Turkey, s.1021-1034.

Cristina Patemo, M. and Elena Charolai, A. (2000). Preliminary studies for the consolidation of Guadalupe tuff from the Philippines. 9 $^{\text {th }}$ International Congress on Deterioration and Conservation of Stone, Venice, p.155-163.

Çapar, E.M. (2019). Bazı küfeki taşlarının fiziksel ve mekanik özelliklerinin karşılaştırmalı olarak incelenmesi (Yüksek Lisans Tezi), i.T.Ü. Fen Bilimleri Enstitüsü, İstanbul.

Çelik, M., Akbulut, H. and Ergül, A. (2013). Water absorption process effect on strength of Ayazini tuff, such as the uniaxial compressive strength. Flexural Strength and Freeze and Thaw Effect. Springer-Verlag, October 6. https://doi.org/10.1007/s12665-013-2819-8

Dal, M. (2008). Vize-Pınarhisar (Kırklareli) bölgesi kalkerlerinin restorasyonda kullanılabilirliği (Doktora Tezi). Trakya Üniversitesi Fen Bilimleri Enstitüsü, Mimarlık Anabilim dalı, İstanbul.

Dal, M. and Tokmak, M. (2020). Durability properties of Silivri limestone and usability in stone building restorations. International Journal of Pure Application Science, 6(1), p.33-41. https://doi.org/10.29132/ijpas.724073

Demir, C. and ilgi, A. (2014). Characterization of the materials used in the multi-leaf masonry walls of monumental structures in Istanbul-Turkey. Construction and building materials, 64, p.398413. https://doi.org/10.1016/j.conbuildmat.2014.04.099

Ediz, i. C. (2002). Mermer ve taş ocağı işletmeciliği. Ders Notları, Dumlupınar Üniversitesi, Kütahya. 
Erguvanlı, K. and Ahunbay, Z. (1989). Mimar Sinan'ın İstanbul'daki eserlerinde kullandığı taşların mühendislik jeolojisi ve mimari özellikleri. Mühendislik Jeolojisi Bülteni, 11, p.109-114. http://www.muhjeoder.org.tr/wp-content/uploads/11_ss.pdf

Eudier, M. (2014). The mechanical properties of sintered low-alloy steels. Powder Metallurgy, 6, p.278-290. https://doi.org/10.1179/pom.1962.5.9.005

Gentürk, A., Gündüz, L. and Sarışık, A. (1995). Yapı ve kaplama malzemesi olarak kullanılan endüstriyel kayaçlara teknik bir bakış. Endüstriyel Hammaddeler Sempozyumu, İzmir, p.331338.

Griffits, T.J., Davies, R. and Bassett, M.B. (2013). Analytical study of effect of pore geometry on tensile strength of porous materials. Powder Metallurgy, 22, p.119-123. https://doi.org/10.1179/pom.1979.22.3.119

Mutluhan, A. and Aydın, O. (2011). Evaluation of the long-term durability of yellow travertine using accelerated weathering test. Bulletin of Engineering Geology and the Environment, 70(1), p.101-114 DOI:1007/s10064-010-0287-x

Theoulakis, P. and Bardanis, M. (2000). The stone of Piraeus at the monuments of the Acropolis of Athens. $9^{\text {th }}$ International Congress on Deterioration and Conservation of Stone, Venice, 1 , p.255-263.

Thomachot, C. and Jeannette, D. (2000). Petrophysical properties modifications of Strasbourg's Cathedral sandstone by black crusts. $9^{\text {th }}$ International Congress on Deterioration and Conservation of Stone, Venice, 1, p.265-273.

TS 1467. (2005). Doğal taşlar-ham bloklar-özellikler. Doğal yapı taşlarının sınıflandırılması, özellikleri, örneklenmesi ve test edilmesi. TSE.

TS 1469. (2006). Doğal taş mamulleri-kaplamada kullanılan plakalar-özellikler. TSE

TS 699. (2009). Doğal yapı taşları-Inceleme ve laboratuvar deney yöntemleri. TSE.

Tuncel, Z. and Arıoğlu, E. (1998). Alçı malzemesinin basınç ve çekme dayanımlarında yükleme hızının etkisi. 4.Ulusal Kaya Mekaniği Sempozyumu Bildiriler Kitabı, Zonguldak, s.83-93.

Umaroğulları, G. (2015). Erken dönem Osmanlı yapılarında kullanılan Trakya bölgesi küfeki taşlarının fiziksel ve mekanik özelliklerinin sonuçları üzerine bir model önerisi (Doktora Tezi). Trakya Universitesi, Fen Bilimleri Enstitüsü, Edirne.

Zarif, H., Tuğrul, A. and Gürpınar, O. (1998). Beton agregası olarak kullanılan Devoniyen kireçtaşlarının litolojik özelliklerinin mekanik özelliklerine etkisi. Jeoloji Eğitiminin 20. Yılı Sempozyumu, Fırat Üniversitesi, Elazığ, s.155. 